\title{
The New Age Movement in the Post-Celtic Tiger Context: Secularisation, Enchantment and Crisis
}

\section{Carmen Kuhling}

\section{Q OpenEdition \\ 12 Journals}

\section{Electronic version}

URL: http://journals.openedition.org/etudesirlandaises/3921

DOI: 10.4000/etudesirlandaises.3921

ISSN: 2259-8863

\section{Publisher}

Presses universitaires de Rennes

\section{Printed version}

Date of publication: 20 November 2014

Number of pages: 101-113

ISBN: 978-2-7535-3559-6

ISSN: 0183-973X

\section{Electronic reference}

Carmen Kuhling, «The New Age Movement in the Post-Celtic Tiger Context: Secularisation,

Enchantment and Crisis », Études irlandaises [Online], 39-2 | 2014, Online since 20 November 2016,

connection on 30 April 2019. URL : http://journals.openedition.org/etudesirlandaises/3921 ; DOI :

10.4000/etudesirlandaises.3921 


\title{
The New Age Movement in the Post-Celtic Tiger Context: Secularisation, Enchantment and Crisis
}

\author{
Carmen Kuhling \\ University of Limerick
}

Abstract

This paper will examine the New Age Movement in Ireland in the context of theoretical debates and empirical trends relevant to the themes of secularisation, commodification and crisis. This paper will reflect on the "secularisation thesis", the Census 2011 data on religion, and the rise of the New Age Movement in the context of the social changes in Ireland which occurred during the "Celtic Tiger" period, as well as changes which have resulted from the economic crisis ${ }^{1}$.

Keywords: Secularisation, liminality, enchantment, crisis, austerity

\section{Résumé}

Cet article examine le Mouvement New Age en Irlande dans le contexte des débats théoriques et des tendances empiriques pertinentes en ce qui concerne les thèmes de la sécularisation, de la logique de marchandisation et de la crise. Il commente la " thèse de la sécularisation", les données relatives à la religion dans recensement de 2011 et la montée du Mouvement New Age dans le contexte des changements sociaux en Irlande à l'époque du "Tigre celtique ", ainsi que les changements qui ont résulté de la crise économique.

Mots clés : Sécularisation, espace-frontière, enchantement, crise, austérité

\section{Introduction: Secularisation and Enchantment in a Global Context}

For centuries, social scientists and intellectuals have predicted that Western modernity will grow increasingly "secular". Although there has always been some debate about this idea of the gradual increase of secularism, or the "secularisation thesis" as it has come to be known, critics of this thesis have grown substantially over the past few decades as global empirical evidence to the contrary has emerged. This concept of secularisation is underpinned by a linear conception of "progress" that

1. Special thanks to Laurence Cox for his very helpful feedback and comments on this paper. 
views modern institutions such as democracy, capitalism and science as accompanied by a series of mutually reinforcing social processes, such as secularisation, rationalisation and disenchantment. Many classical and contemporary sociological paradigms assume that societal evolution is accompanied by the unfolding of these institutions. However, the global spread of these institutions has been inconsistent and uneven, and religious movements and belief systems have encroached upon the public sphere and public morals in all kinds of subtle and contradictory ways in both the West and the wider world. This paper will examine this secularisation thesis with reference to the recent social trends in Ireland which both confirm and contradict this thesis. The secularisation of educational and health systems combined with a decline in religious practices would seem to confirm this hypothesis, yet the high proportion of self-proclaimed Catholics and the emergence of New Religious Movements in Ireland, particularly New Age Spiritualities, contradict this thesis, and reflect broader global trend towards "post-secularisation" rather than secularisation. In fact, the proliferation of a range of New Age Spiritualities which are emerging in Ireland with increasing frequency in the past two decades are clear examples of this re-enchantment and postsecularisation, and demonstrate the co-existence of such post-secular and secular impulses within Irish society. I will demonstrate how Ireland is simultaneously presecular, secular and post-secular; it is both enchanted and disenchanted.

Typically the social sciences have taken up the position that the separation of religion from public life and particular social institutions such as education and health is evidence of increasing secularisation. However, the growth of traditional religions at a global level, the resurgence of religiosity within in the heartland of Western modernity, and the increasing popularity of the New Age Movement and other New Religious Movements all call into question the idea that modernity contains a linear, progressive evolution towards disenchantment and secularisation. Berger, Davies and Fokas provide empirical evidence which contradicts this secularisation thesis and argue that it is European secularisation rather than American religiosity that is the global anomaly ${ }^{2}$. The increased levels of religiosity recorded in the US and other countries have revealed that modernity, far from being accompanied by increased secularisation, defies any linear chronology, and

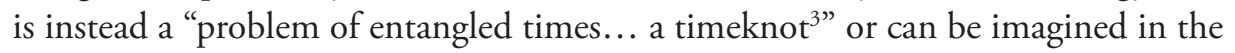
words of Nead, "as pleated or crumpled time, drawing together past, present and future into constant and unexpected relations ${ }^{4}$ ". Saler however cautions that "the

\footnotetext{
2. P. Berger, G. Davies and E. Fokas, 'Introduction' in Religious America, Secular Europe? A Theme and its Variations. P. Berger, G. Davies and E. Fokas (eds), Farnham, Surrey, Ashgate, 2008, p. 12.

3. D. Chakrabarty, Provincialising Europe: Postcolonial Thought and Historical Difference. New Jersey, Princeton, 2000, p. 243.

4. L. Nead, Victorian Babylon: People, Streets and Images in Nineteenth Century London. New Haven, Yale University Press, 2005, p. 8.
} 
seeming 'universal' distinctions championed by the Western metropole between modernity and tradition or secularisation and superstition often do not hold up when viewed from the periphery of non-Western cultures negotiating processes of modernisation in complex ways". Saler critiques this binary approach for relegating enchantment to the status of a residual, inferior "other" to the rational and secular tenets of modernity, and claims those who sought alternatives to this model have been characterised as nostalgic, reactionary anti-modernist holdovers from the pre-modern world. He argues instead that "modernity is less defined by binaries arranged in an implicit hierarchy, or by the dialectical transformation of one term into its opposite, than by unresolved contradictions and oppositions, or antinomies ${ }^{6 "}$. The seemingly universal distinctions between tradition and modernity, religion and reason, and superstition and secularism which this secularisation thesis presupposes are deeply problematic from the point of view of non- Western societies, many of whom are modernising in ways which diverge from the path taken by the West. Empirical research and theoretical debates emerging from the controversy around secularisation have therefore provoked a radical rethinking of the nature of modernity, and have provided evidence for the idea of "multiple modernities".

The idea that modernisation and secularisation proceed in tandem, which is a central assumption of the secularisation thesis, has dominated sociological thinking for the past 150 years. In his essay "Science as a Vocation" Weber says the "fate of our times is characterized by rationalisation and intellectualisation and, above all, by the 'disenchantment of the world'"'. He was referring to the way in which modern processes of bureaucratisation, rationalisation and secularisation were accompanied by a corresponding loss of transcendent meaning, animistic connection, and magical expectations that characterised the premodern world. Thus Weber was articulating a critique shared by the Romantics of the late $18^{\text {th }}$ century and developed by cultural critics throughout the $19^{\text {th }}$ and $20^{\text {th }}$ centuries of the ways in which Enlightenment science and reason had eclipsed other epistemological views of the world. In the words of Saler, "Enchantment was associated not only with transcendent meaning and purpose, but also with wonder and surprise; these were the qualities that modernity, with its emphasis on inviolable natural laws, threatened to extirpate ${ }^{8 ”}$. By the late $19^{\text {th }}$ century, the mechanistic, scientific view of positivism was so deeply inculcated in the modern

\footnotetext{
5. M. Saler, "Modernity and Enchantment: A Historiographic Review", American Historical Review 111, 2006, p. 700.

6. Ibid.

7. M. Weber, "Science as a Vocation." In From Max Weber: Essays in Sociology, Hans Heinrich Gerth and C. Wright Mills, New York, Routledge, 1946, p. 129.

8. M. Saler, op. cit. p. 695.
} 
mind that in Weber's words, "the world is disenchanted". This produced a narrative of modernity and disenchantment that equated a narrow, soulless instrumental rationality with a "hollow, expanding secularism permeating the West since at least the $17^{\text {th }}$ century ${ }^{10}$ ". Weber was not as deterministic as is often assumed with regards to the shift towards what he calls the "iron cage" of rationalisation and secularisation, since in The Protestant Ethic and the Spirit of Capitalism he makes it clear that a variety of futures are possible, including a growth in new prophets, a rebirth of old ideals, as well as a rise in secularism. Nonetheless, Weber is often assumed to be the author of deterministic versions of the secularisation thesis, and the nuances of his analysis are often overlooked.

This assumption that modernity would be accompanied by the presumed linear increase in secularisation, rationalisation and disenchantment has been contradicted by empirical evidence. Indeed, the crossovers between political/ social science and the theological have become so numerous in recent years that one can now speak of the "theological turn" in modernity studies, the increasing prominence in the past few years of political theology, and the growing body of research that defines itself as "post-secular". For instance, the last quarter of the $20^{\text {th }}$ century was accompanied by increased levels of religiosity in the US. Berger et al. in their book Religious America, Secular Europe argue that it is European secularisation rather than American religiosity that is the global anomaly ${ }^{11}$. Specifically, they show how within this general pattern of what they call Eurosecularisation, there are national and regional differences, with Ireland and Poland as the most religious countries. They demonstrate how despite the prevalence of Eurosecularisation, the rise of Pentecostalism across the developing world, the growth of Christianity in the southern hemisphere, the intrusion of Islam in global political affairs, and the increase in a specific kind of religiosity in the US all indicate that it is Europe, rather than the US, that is exceptional. There are, they argue, strong variations and complex and polarised power configurations in the US. Yet at a global level, even the high levels of religiosity in the US is strongly eclipsed by the exponential growth of Christianity in the developing world, and specifically in the global south, a growth that Jenkins argues outstrips the growth of the much discussed expansion of Islam in the late $20^{\text {th }}$ century. 


\section{图 From Celtic Tiger to Austerity: Commodification, Crisis and Disenchantment in Ireland}

The Republic of Ireland has long been considered an exception to the overall European trend towards secularisation, and Catholicism has long been considered a central aspect of Irish identity. During the later $19^{\text {th }}$ and $20^{\text {th }}$ centuries, the Catholic Church exerted a great deal of control over welfare and educational institutions, and the rapid growth in power of the Catholic Church in Ireland up until the 1960s meant that being "Irish" came to be equated with being "Catholic". The level of religious adherence and affiliation in Ireland is still reasonably high by international standards, since $84 \%$ of the population still claim to be Catholic, but has been dropping steadily since its highest recorded rate of 95\% in 1961 . The 2011 census data reveals a quite significant growth in numbers who claim no religious affiliation in Ireland in recent years, since approximately 270,000 people defined themselves as being of no religion, an increase of 44 per cent on the 2006 census. The number of those with no religion, atheists and agnostics increased more than fourfold between 1991 and 2011, and there are some indications that this number could in reality be much higher. For instance, Macourt has argued that the 2006 census had too few categories and was far too narrowly defined to adequately capture the number of people who are consciously resisting religion, or the diversity of the contemporary Irish spiritual or religious landscape ${ }^{12}$. Similarly, Nic Ghiolla Phadraig also claims that high numbers of self- proclaimed Catholics is not an accurate indicator of religious affiliation. To her, this category is more of an indicator of cultural or national identity which has been historically constructed against British colonial occupation whereby the identities of Irish and Catholic are conflated ${ }^{13}$. Using 2008 ISSP data, she demonstrates that the number of those who attend Church once a week fell from $91 \%$ in 1973 to $43 \%$ in 2008 , and that this drop was particularly high amongst young people aged 18-24, whose Church attendance fell to only $19 \%$. As well, she shows that $16 \%$ of these self- declared Catholics claimed to be atheist, agnostic or do not believe in God. The fact that some individuals do not attend church or believe in God yet still self- identify as Catholic raises some questions as to what the category "Catholic" actually means according to Nic Ghiolla Phadraig ${ }^{14}$. It is perhaps revealing that data on religious practice amongst the 18-24 age group young is largely hidden

12. M. Macourt, Chapter 2: Mapping the "New Religious Landscape and the 'New Irish'; Uses and Limitations of the Census", in O. Cosgrave, L. Cox, C. Kuhling and P. Mulholland (eds), Ireland's New Religious Movements. Newcastle Upon-Tyne, Cambridge Scholars Press. p. 28-51.

13. M. Nic Ghiolla Phadraig "Religion in Ireland: No Longer an Exception?" Academic Register's Council Research Update no. 64, December 2009. [http://www.ark.ac.uk/publications/updates/update64.pdf] (accessed November $\left.21^{\text {st }}, 2013\right)$.

14. Ibid. 
in 2011 Census data, yet detailed information is given in other areas (religion by county, religion of school children) which are much less political. On one hand, as Inglis argues, "much of the Catholic habitus lingers on, deeply embedded in our people's identity and sense of self" $(2004,13)$, yet on the other hand, as Macourt insists, the lack of complexity in Census questionnaires reveal the implicit pressure on individuals to self- identify as Catholic. All these issues raised above reveal the fact that unprecedented levels of economic modernisation and globalisation combined with the various crises of the Catholic church in Ireland have contributed in some ways to a transition from what has been called a "traditional', highly devotional society to a modern, increasingly secular one ${ }^{15}$ ". The exposure of child sexual and physical abuse within religious institutions combined with unprecedented levels of globalisation, economic modernisation and other national factors facilitated a decline in the institutional power of the church in the last 40 years.

However a linear view that modernisation is inevitably accompanied by an increase in secularisation, a view that has been caricatured as "modernisation up, religion down ${ }^{16 "}$ is in some ways an oversimplification in the Irish case. The growth in New Religious Movements in Ireland in some ways challenges linear, triumphalist versions of history, and calls into question our ideas about the nature of social progress. While there is some evidence of secularisation, at the same time data from the last 20 years shows that Ireland's new multiculturalism has been accompanied by a rise in Orthodox, Pentecostal/ Apostolic, Muslim, Hindu and Buddhist religions, as well as an increase in those from Protestant religions such as Church of Ireland. Because of the narrow range of categories and questions on the Irish census, it is difficult to get clear figures on rates of religious conversion, but there is significant evidence that some Irish people who were raised Catholic have converted to other religions such as Buddhism and Evangelical religions. Elsewhere, sociologists have noted a shift towards Mysticism, Paganism and other so called New or New Age religions ${ }^{17}$. The coexistence of increasing number of individuals who deny any religious affiliation alongside high numbers of self-proclaimed Catholics (as well as members of a range of the New Age and New Religious Movements) demonstrates how Ireland simultaneously inhabits pre-secular, secular and post-secular modernities; is simultaneously enchanted and disenchanted. Bauman's notion of "liquid modernity" captures this idea that there is no singular modernity, single modern world, or a singular linear process of modernisation that is brought into being; there are rather multiple modernities, mul-

\footnotetext{
15. H. Tovey, P. Share and M. Corcoran. Sociology of Ireland, 3rd ed. Dublin, Gill and Macmillan, 2007. p. 403.

16. Costopoulos, Phillip. "Introduction." In World Religions and Democracy, L. Diamond, M. Plattner and P. Costopoulos (eds), Baltimore, Johns Hopkins University Press, 2005, p. x.

17. See "introduction" in O. Cosgrave et al., op. cit.
} 
tiple invented "traditions", a plurality of modern worlds, and multiple processes of modernisation ${ }^{18}$. As we have seen, modernity does not necessarily bring about secularism, but rather a kind of religious pluralism. As Berger et al. put it, religion is no longer taken for granted but has become more of a reflexive process and an object of individual reflection and decision ${ }^{19}$.

Yet from another point of view, Ireland's Celtic Tiger years were a time of enchantment, and practices associated with consumption have to some degree taken over the ritual, meaning- making functions previously fulfilled by religion. The oxymoronic term "Celtic Tiger" was formerly been adopted as a potent image that captured various dimensions of the country's recent economic boom such as the ambivalent nature of socioeconomic change and collective cultural identity. The contradictory images and temporalities underpinning the term "Celtic Tiger" revealed the tensions of this binary approach to enchantment/ disenchantment. For instance, the term "Celtic" conjured up an image of an "Enchanted Ireland"; a pre-modern, Romantic, mist-shrouded, "timeless arcadia, the province of fairytale and myth" ${ }^{20 "}$. In contrast, the term "Tiger", borrowed from the Asian economic model, invoked the rhetoric of competitive individualism, survival of the fittest, and denotes the shift in Ireland towards a laissez faire, neoliberal ideology during the Celtic Tiger era ${ }^{21}$. "Tiger" also connoted a "disenchanted", "cyborg" Ireland that was a fast-paced, (post) modern and global exemplar of the new informational economy, and is characterised by the instantaneous "accelerated time" of futuristic science fiction and cyberculture. However, official state policy during the Celtic Tiger economic boom, governed by so called "rational choice" economic theory and financialisation of markets, explicitly repressed the values of community and collectivity in favour of a "disenchanted", neo-liberal form of rationalised acquisition; one that prioritised economic "growth" over social cohesion. In the 1990s, Ireland embraced free-market and neoliberal principles and aggressively courted foreign direct investment, which led to a rapid shift to high-skilled manufacturing, a growth in the service sector, and the development of a domestic consumer society. Irish people's collective self- understanding self- definition, formerly organised around the dual pillars of Catholicism and Nationalism as higher ideals, came slowly to reside in the principles of Neoliberalism during the time of the Celtic $\operatorname{Tiger}^{22}$. Astronomical rates of spending in what Ritzer calls "cathedrals of consumption" ${ }^{23}$ ", particularly around Christmas

18. Bauman, Zygmunt. Liquid Modernity. Cambridge, Polity, 2000.

19. Berger et al., op. cit. p. 13.

20. M. Cronin, and B. O'Connor, "Introduction", in Michael Cronin and Barbara O'Connor (eds), Irish Tourism: Image, Culture and Identity, Clevedon, Channel View Publications, 2003, p. 1-18.

21. D. O'Hearn, Inside the Celtic Tiger: The Irish Economy and the Asian Model, London, Pluto Press, 1998.

22. F. O'Toole, Enough is Enough, London, Faber \& Faber, 2010.

23. G. Ritzer, Enchanting in a Disenchanting World, London, Sage, 2010, p. 3. 


\section{Carmen Kubling}

in the early part of the decade (when Irish Christmas spending outstripped other EU countries, and even the US) have led to the somewhat accurate claim in the media that Irish spiritual life has shifted "from the parish hall to the shopping mall". Morante described how in the US, the class of financial operators, investment bankers, traders, hedge fund managers and private equity fund managers emerged were idealised, and considered to be "titans of investment banking", "leviathans", "masters of the universe" or "high priests of finance" in both the City and Wall Street ${ }^{24}$. Thus in Ireland, the Celtic Tiger years were a time of decreasing enchantment with the Catholic Church, but increasing enchantment with neoliberal globalisation. The "God-like" status of economism and neoliberalism in the collective Irish imaginary is revealed by the fact that prior to the crisis, individuals in Ireland felt that the banks were "too big to fail". Morante shows how in the US after the global financial crisis occurred there was a collective illusion "shared by investors in all sectors of society, from financial operators to educated, sophisticated, wealthy individuals and the so called sub-prime borrowers that the financial sector, like a benevolent God, would provide effortless and endless rewards ${ }^{25}$ ". This belief in the magic, God- like characteristics of the market and unquestioned faith in the high priests of finance justified the "light touch" regulation in Ireland as well. Despite extensive critiques of these economic principles, this belief in the omnipotence of the market "remains the bedrock of how conventional wisdom views the financial system, the key premise upon which we conduct monetary policy and the framework on which we construct our financial risk systems ${ }^{26 "}$. In both contexts, entrepreneurial culture is highly valorised, and bankers are profoundly idealised. In many ways, the unquestioned faith in the texts, apostles, cathedrals and rituals associated with Catholicism have simply been superseded by unquestioned faith in texts, apostles, cathedrals and rituals associated with consumption, and which are bound to the mythologies of economism and neoliberalism.

The dual character of the commodity is such that it is simultaneously enchanted and disenchanted, for it circulates within systems of production/desire that are animated by both political and libidinal economies. Benjamin perhaps best articulates the enchanted, reified, religious nature of commodity fetishism, by stating that the commodity is the idol of modernity... the arcades, the boutiques and the department stores are shrines to thecommodity, they are its temples where one goes to pay homage ${ }^{27}$. According to Žižek, the commodity form is of such fasci-

\footnotetext{
24. F. Morante. "Omnipotence, Retreat from Reality and Finance: Psychoanalytic reflections on the 2008 crisis" in International Journal of Applied Psychoanalytic Studies, Vol 7, Issue 1, 2010, p. 4-21.

25. Ibid. p. 8.

26. Cooper, 2008, p. 11.

27. G. Gilloch, Myth and Metropolis: Walter Benjamin and the City, Cambridge, Polity, 1996, p. 119.
} 
nation because it provides us with a little piece of the Real, a pure distilled matrix which "enables us to generate all other forms of the 'fetishistic inversion'28". Many Irish people have capitulated to the neo-religion of consumerism, and this dialectic of enchantment/disenchantment can be seen through an analysis of the libidinal/ political economy of the Irish house, which on one hand is treated as pure materiality, as "real estate", and on the other hand, as the "dream home". The home, land and property have long held a central place in the Irish imaginary, and within the Celtic Tiger context, the home became the ambivalent repository of collective fears and desires. Lee provides a compelling formulation of the institutionalization of a characteristic mindset amongst the Irish peasantry during the second half of the 19th century, wherein, as a response to extreme insecurity of tenure the central focus of both private life and the public sphere centred around the "possessor principle": all political questions boiled down to the question of real estate, and individual life strategies centred on the acquisition and retention of house and homestead as private property ${ }^{29}$. However, this "possessor principle" has so animated Irish life that in the ten years between 1995 and 2005, there were 584,073 new houses built, a substantial increase in a population of just over 4 million $^{30}$. The pre-crash rise in the number and size of houses, the numbers of gated communities, and the astronomical rise in prices achieved for high status postcodes and during the Celtic Tiger years clearly demonstrates the performative function of the home as "cathedral" where one can showcase one's techniques of elite, conspicuous consumption. However, the home is not simply real estate, bought for its exchange value, but rather its value is simultaneously primordial and transcendent. What is "real" about real estate is that it stands in the place of what Lacan terms the Real: the abyss of nothingness and meaninglessness over which human existence is suspended ${ }^{31}$. The idea of home and belonging resonates with deep seated anthropological needs that are both material and spiritual, and it is at times of material and/or spiritual insecurity that the house assumes an amplified value - hence the saying "as safe as houses ${ }^{32}$ ". For Benjamin, the house retains a utopian potentiality, for it is a repository of the memory of a deeper, richer, collective life that transcends the eternal recurrence of the present as monadic individualism, for it retains traces of a childhood memory of a lost ideal that might be recollected $^{33}$.

28. S. Žižek, The Sublime Object of Ideology, London, Verso, 1989, p. 16.

29. Lee, Joe, Ireland: 1912-1985, Cambridge, Cambridge University Press, 1989.

30. CSO, 2006 K. Whelan, Atlas of the Irish Rural Landscape, Cork, Cork University Press, 2012, p. 353.

31. J. Lacan, The Four Fundamental Concepts of Psychoanalysis, New York, Norton, 1978.

32. K. Keohane and C. Kuhling, The Domestic, Moral and Political Economies of Post-Celtic Tiger Ireland: What Rough Beast?, Manchester, MUP, 2014, p. 20.

33. W. Benjamin. "A Berlin Childhood around 1900." In Walter Benjamin Selected Writings: 1935-1938, Volume 3, by W. Benjamin, H, Eiland and M. Jennings (eds), Cambridge, Harvard University Press, 2002, p. 344-414. 


\section{The New Age Movement in Ireland}

The New Age Movement has been quite influential in shaping various political, religious, and popular discourses in both North America and Europe in recent decades. The New Age is not a unified movement or coherent cultural phenomenon, but rather can be understood as a series of concentric circles, some of which overlap significantly with environmentalism, feminism, anti-consumer politics, and some of which are perfectly consistent with individualism, capitalism and consumption. In the Irish context, this eclectic mix of Eastern mysticism, self-help therapy, Paganism, and holistic health, can be understood as a response to what some people experience as an oppressive Catholicism on one hand, and the spiritual vacuum at the heart of late capitalism on the other ${ }^{34}$. Despite the common description of Ireland as religiously very homogeneous in the $19^{\text {th }}$ and $20^{\text {th }}$ centuries, many New Religious Movements (NRMs) come to Ireland in the nineteenth century, including theosophists, spiritualists and astrologers ${ }^{35}$. Mulholland also describes the increase in folk healers, UFO sightings, occultism, tarot card readers, water diviners, yoga, and witchcraft groups in the 1960s and $1970 s^{36}$. However, this movement has become particularly visible since the 1980 s as part of the Mind-Body-Spirit movement which flourished when the MindBody-Spirit fair first came to Dublin in 1985, and which functions as an umbrella for many of the groups, beliefs and practices that constitute the New Age Movement in Ireland ${ }^{37}$. While the Mind-Body-Spirit movement occupies perhaps the more commodified, individualised end of the New Age spectrum, the Quay coop in Cork which began as an alternative community project by feminist, lesbian $\&$ gay, environmental and other alternative groups published the Alternative Ireland Directory from 1981-1993, which contains elements of both new social movements (ecology, gay rights) and the New Age. However, the New Age Movement in Ireland is not only strong in urban centres, for places such as the West Cork Dzogchen Beara, a Tibetan Buddhist Retreat centre running since 1992 on the Beara peninsula near Allihies have also been considered attractive to those interested in the New Age. Cox has painstakingly traced out the quite rich and deep history of Buddhism and Ireland, and though Buddhism and the New Age Movement are clearly quite distinct movements, he has noted how the New Age movement and Buddhism both have been positioned as "Christianity's Other" ${ }^{38 \text { ", and }}$

34. C. Kuhling, The New Age Ethic and the Spirit of Postmodernity, New Jersey, Hampton Press, 2004, p. viI.

35. O. Cosgrove, L. Cox, C. Kuhling and P. Mulholland, 'Editors' Introduction' in O. Cosgrove, L. Cox, C. Kuhling and P. Mulholland (eds), op. cit. p. 8.

36. P. Mullholland, "Moving Statues and Concrete Thinking." Quaderns de l'Institut Català d'Antropologia: sèrie monogràfics 23, 2009, p. 159-179.

37. Ibid. p. 10.

38. L. Cox, Buddhism and Ireland: From the Celts to the Counter-culture and Beyond. Sheffield, Equinox, 2013, p. 13. 
both have been condemned by the Irish Theological Commission and by other pro-Christian, anti-cult organisations ${ }^{39}$, and there are some overlaps in terms of their beliefs, practices and community members. Similarly, Butler has observed the interconnections between Irish neo-Paganism and the New Age movement, but cautions that neo-Pagans would reject the term "New Age", as Butler notes, the term "New Ager" is considered offensive to some neo-Pagans as "whimsical rituals that have no serious spiritual intent ${ }^{40 "}$ ". Nonetheless, an analysis of New Age Bookshops, magazines, and spaces such as the Quay Coop and the book shop in Dzogchen Beara reveal a significant overlap between the interests of Buddhists, Neo-Pagans, and the New Age Movement, or at the very least the New Age Movement's ability to appropriate countercultural movements and alternative spiritualities into its fold.

The New Age Movement in the 1980s and early 1990s was seen as containing elements of a countercultural political culture, and as a more non-hierarchical, unstructured, DIY, or "patchwork" religion. Berger argues that humans have a deep-seated anthropological need to construct a "sacred canopy", a "shield against terror" or a "cultural nomos" that "guarantees members of society the experiential certainty that their lives are an integral part of a higher reality, one whose cohesion stems from a cosmic, suprahuman ordering principle ${ }^{41}$ ", and for some, the New Age filled a gap left by Catholicism. New Age literature and practices contain liberal reference to terms like reconciliation, integration, re-enchantment and rebirthing, which reveals the profoundly utopian desire for a richer spiritual life, for connectedness with others, for a union with nature, for health, for wholeness. This New Age desire for reconciliation and re-enchantment can be seen by the interest in neo-Pagan rituals, Celtic mysticism, and other pre- or non-Christian ceremonies. This appeal to the order of the "supernatural": to New Grange, to the dolmens, and to stone circles and Pagan sites around Ireland is because these are liminal sites of highly symbolic but contested meaning. These "enchanted" spaces in the New Age imaginary are liminal sites which provide the possibility for the constitution of ambivalent identities and of a new social ordering wherebythe problematic conditions of work and consumption under global capitalism, can be transgressed, resisted, and then re-ordered.

However, since the economic crisis and the imposition of a brutal austerity regime in Ireland, the need for spiritual rejuvenation has become even more acute. We are living in a time of radical uncertainty, which for some has intensified this need for a "cultural nomos" or sacred canopy. Yet, as a result of neoliberalisation and the Celtic Tiger economic boom, this movement has become mainstrea-

39. Ibid.p. 318-319.

40. J. Butler, "Irish Neo-Paganism : World View and Identity" in O. Cosgrove et al., 2011, p. 113.

41. R. Griffin, Modernism and Fascism, London, Palgrave, p. 74. 


\section{Carmen Kubling}

med, and it is increasingly commodified for New Age consumers, on one hand, and increasingly "credentialised" by New Age producers who out of economic necessity are seeking accreditation for their various therapeutic and healing practices. For example, Martin Duffy, the director of the nonprofit organisation The Oaktree Trust (which runs the Irish Centre for Shamanic Studies and The Transpersonal Institute), says "there are a lot of problems being caused by the economic climate, and not a lot being done to address them... we want to make sure that people that are financially challenged have access and support ${ }^{42}$ ". Similarly, psychiatrist Norman Rosenthal says: "Economic challenges, the feeble job market and information overload conspire to stretch people to breaking point... and has resulted in cardiovascular disease as well as psychiatric disorders... Having witnessed the mental and spiritual anguish of many hundreds of people... I find the potential clinical power of this technique (Transcendental Meditation) amazing ${ }^{43}$." In the absence of other options, people are turning to New Age selfspirituality as a remedy for social ills, and more and more technologies and services are emerging to fill this need. However, those most hard-hit by austerity measures lack the financial resources to access such services or technologies both as consumers and producers. While the utopian energy of the New Age Movement is still alive in Ireland, another much more dystopian spiritual metaphor is present in Ireland: the image of the zombie. This image has been used with increasing frequency not only when referring to the banks as "zombie institutions" as dead-live entities continue to feed of the state, but also as a symptom of an exploitative society, as a metaphor for a compromised, distorted colonized subjectivity and for the breakdown of social solidarities since the economic crisis which is expressed in popular cultural form as the "zombie apocalypse". Since the recession has hit, we are in a period of liminality; standing on the limen or sacred stone of the doorway marking the threshold, we are in a portal between one dimension and another, and do not know what the future will hold.

\section{Conclusion}

In this way, the New Age movement is an anchor, or a site of identity in the context of liquescence and permanent liminality of modernity ${ }^{44}$; the destabilization of the fiscal and legal bases of national citizenship and the identity insecurities of the postnational constellation ${ }^{45}$ as well as the ephemerality of postmodern

\footnotetext{
42. D. Phillips, "The Future of Network Magazine: an interview with Martin Duffy" in Network Magazine, Nov 6, 2011, accessed online on Dec 20 2013 at: [http://networkmagazine.ielarticles/future-network].

43. N. Rosenthal in "Transcendence: Healing and Transformation" in Network Magazine, Oct 11, 2012.

44. A. Szakolczai, Reflexive Historical Sociology. London, Routledge, 2000.

45. J. Habermas, The Postnational Constellation, London, Verso, 2001.
} 
culture and accelerated social transformation. Economic goods become dematerialized in the knowledge economy, and this process of dematerialisation becomes further perpetuated in flexibilized labour markets and transnational production systems, and in global financial and futures markets. A part of the appeal of the New Age movement is that it appears to offer protection from the infinities and abysses of the modern ontological and epistemological condition of "transcendental homelessness" where, as Lukacs put it "we are all secular, but yearning for the sacred, ironic, but yearning for the absolute, individualistic, but yearning for the wholeness of community, asking questions, but receiving no answers, fragmented, but yearning for imminent totality ${ }^{46 "}$. It offers an antidote to spiritual malaise and our current condition of "transcendental homelessness". 